\title{
BİLGİ İFŞASI (WHISTLEBLOWING) FARKINDALIĞI: GELECEĞİN MESLEK MENSUPLARI ÜZERINE BİR ARAŞTIRMA
}

Araştırma Makalesi / Research Article

\author{
Erdoğan, M. ve Oruç Erdoğan E. (2021). Bilgi İfşası \\ (Whistleblowing) Farkındalığı: Geleceğin Meslek \\ Mensupları Üzerine Bir Araştırma. Nevşehir Hacı \\ Bektaş Veli Üniversitesi SBE Dergisi, 11(1), 163-181. \\ DOI: https://doi.org/10.30783/nevsosbilen.871408.

\author{
Dr. Öğr. Üyesi Murat ERDOĞAN \\ Akdeniz Üniversitesi, İIB Fakültesi, İşletme Bölümü \\ muraterdogan@akdeniz.edu.tr \\ ORCID No: 0000-0002-4506-0731 \\ Dr. Öğr. Üyesi Eda ORUÇ ERDOĞAN \\ Akdeniz Üniversitesi, İ̉B Fakültesi, İşletme Bölümü \\ edaoruc@akdeniz.edu.tr \\ ORCID No: 0000-0003-1507-4232
}

\begin{abstract}
ÖZ
İşletmelerde ortaya çıkan ahlaki, etik ve yasa dışı davranışlar işletme ile ilişkili tüm paydaşların önemli kayıplar yaşamasına neden olmaktadır. Söz konusu kayıplara neden olan eylemlerin ve bu eylemleri gerçekleștiren kimselerin sayısı her geçen gün artmakla birlikte ahlaki, etik ve yasalara uygun davranan çalışanların da var olduğu ve bu bakış açısına sahip kişilerin söz konusu olumsuzlukları önleyici ve tespit edici bir reaksiyon gösterdikleri bir gerçektir. Bu kapsamda yaşanılan birçok finansal skandal, skandalın gerçekleştiği organizasyonda yer alan çalışanlar tarafindan ihbar edilmekte ve ortaya çıkarılmaktadır. Örnek olarak Suistimal İnceleme Uzmanları Derneğinin (ACFE) 2018 yılında yayınlamış olduğu raporda hile eyleminin ortaya çıkarılmasında en yüksek pay (\%33) çalışanlara ait olduğu sonucu bu durumu desteklemektedir. Bu yönüyle ele alındığında bilgi ifşası söz konusu olumsuzlukların ortaya çıkartılmasında önemli bir rol oynamaktadır. Bu açıklamalar kapsamında bu çalışma bilgi ifşası üzerine kurulmuş ve çalışmada geleceğin muhasebe meslek mensubu adayları olan İktisadi ve İdari Bilimler Fakültesi İşletme Bölümü lisans öğrencileri, yüksek lisans öğrencileri ve Ticaret Liseleri öğrencilerinin bilgi ifşasına ilişkin görüşlerinin değerlendirilmesi üzerine odaklanılmıştır. 2020 Aralık- 2021 Ocak döneminde gerçekleştirilen anket çalışması sonuçları genel olarak değerlendirildiğinde, katılımcılar ihbarcılığın gerek işletme gerek çevre gerekse kamu yararını korumak için olması gereken bir davranış biçimi olduğunu belirtmektedirler.
\end{abstract}

Anahtar Kelimeler: Bilgi İfșası, Etik, Etik Davranışlar, Muhasebe ve Finansman.

\section{AWARENESS OF WHISTLEBLOWING: A RESEARCH ON FUTURE PROFESSIONAL MEMBERS}

\begin{abstract}
Moral, ethical and illegal behaviors that occur in businesses cause all stakeholders related to the business to experience significant losses. Although the number of actions causing the losses in question and the number of those who carried out these actions is increasing day by day, it is a fact that there are also employees who act in accordance with the moral, ethical and lawfulness and that people with this point of view show a preventive and detecting reaction to these negativities. Many financial scandals experienced in this context are reported and revealed by the employees of the organization where the scandal took place. For example, in the report published by the Association of Fraud Investigators (ACFE) in 2018, the result that employees have the highest share (33\%) in revealing the act of fraud supports this situation. In this respect, disclosure of information plays an important role in revealing these negativities. Within the scope of these explanations, this study was founded on information disclosure and the study focused on the evaluation of the opinions of the students of the Faculty of Economics and Administrative Sciences Department of Business Administration, graduate students and Commercial High School students, who are the candidates of the future
\end{abstract}


accounting profession, on information disclosure. When the results of the survey conducted between December 2020 and January 2021 are evaluated in general, the participants state that whistleblowing is a form of behavior that should be in order to protect both the business, the environment and the public interest.

Keywords: Whistleblowing, Ethics, Ethical Behaviors, Accounting and Financial.

\section{GİRIŞ}

İşletmelerde yaşanan ve sonuçları itibariyle küresel düzeyde yankı uyandıran (Enron, WorldCom, Parmalat vb) finansal skandallar iç ve dış paydaşların ciddi kayıplar yaşamalarına neden olmuştur. Yaşanılan skandallar tüm paydaşların muhasebe ve finans alanı ve bu alanda görev yapan meslek mensuplarının da ciddi şekilde eleştirilmelerine ve sorgulanmasına neden olmuştur (Alleyne vd., 2013: 36). Skandallar sonucunda kurumsal yönetim, etkili denetim, gözetim ve iç kontroller vb. gibi farklı odak noktalarına ilişkin çalışmalar yürütülmüştür. $\mathrm{Bu}$ odak noktalarından biri de bilgi ifşası olarak adlandırılan "whistleblowing" kavramıdır (Aktan, 2006: 1). Miethe ve Rothschild (1994) bilgi ifşasını bir kurumdaki kötü yönetim, israf, hile ve suiistimal vb diğer suç faaliyetlerini ortaya çıkarma ve kontrol etme açısından son derece önemli bir kavram olarak dikkat çektiğini ifade etmiştir (Label ve Miethe, 1999: 87). Miceli, Near ve Dworkin (2009) bilgi ifşasının etkin ve zamanında yapılarak bir işletmenin ortaya çıkan olumsuz durumu hızlı bir şekilde değerlendirebileceğini, oluşabilecek mali zararını ve yaşanabilecek itibar kaybını önleyebileceğini ve işletmenin organizasyon kültürünü geliştireceğini ifade etmektedir.

$\mathrm{Bu}$ çalışmada, işletmelerde çeşitli pozisyonlarda görev üstlenecek olan, muhasebe ve finansman meslek mensuplarının etik davranışları kapsamında ele alınan bilgi ifşası kavramı temel alınarak, geleceğin muhasebe ve finansman meslek mensupları olarak beklenen Ticaret Liseleri, İktisadi ve İdari Bilimler Fakültesi İşletme Bölümü lisans ve yüksek lisans öğrencilerinin bilgi ifşasına iliş̧kin görüşleri değerlendirilmiştir.

\section{BILGİ İFŞASI (WHISTLEBLOWING) KAVRAMI}

"Whistleblowing" teriminin kökeni bir polisin suça yönelik bir davranışı engellemek ve ilgili kişiye uyarıda bulunmak amacıyla ıslık çalması şeklinde kullanılmaktadır (Candan ve Kaya, 2015: 308). "Whistleblowing", Türkçe'de "1slık çalmak", "üflemek" olarak ifade edilebilmektedir. Yabanc1 literatürde kelimenin esas anlamı bir kişinin dikkatini çekme, sesini duyurma anlamında kullanılmaktadır. Literatürde "organizational wrongdoing / misconduct ", "malpractice" olarak da kullanılmaktadır (Celep ve Konaklı, 2012).

Bir işletmede gerçekleşen dolandırıcılık veya kötüye kullanımın ihbar edilmesi olarak belirtilen whistleblowing, bir kuruluşta çalışmış veya halen çalışmakta olan kişilerin kurumlarında gerçekleşmiş veya devam eden yasa ve etik dışı davranışların bu davranışlara son verebilecek kişi ya kuruluşlara açıklaması, iletmesi, dikkatini çekmesi şeklinde de tanımlanabilir (Near ve Miceli, 1985: 4; Öztürk, 2019: 4)). King (1999) "whistleblowing" kavramını bir kuruluşta ortaya çıkan ve ahlaki kurallara aykırı olan davranışların ilgili kuruluşta yer alan diğer kişiler tarafından ortaya çıkarılması olarak tanımlamıştır. Söz konusu tanımlamalardan sonra bu çalışmada "whistleblowing" kavramı "bilgi ifşası" olarak ele alınacaktır.

\section{BILGII İFŞASININ ÖNEMI}

İşletmelerde ortaya çıkan ahlaki, yasal ve etik olmayan uygulamaların ortaya çıkarılması sürecinde kullanılan bir yöntem olarak bilinen bilgi ifşası kamu ya da özel sektör ayrımı yapılmaksızın tüm organizasyonlarda ortaya çıkabilmektedir (Kozak ve Şahin, 2018: 31). Özellikle Enron skandalından sonra bilgi ifşasının önemi artmıştır. Bilgi ifşası, ifşa edilecek olaydan etkilenebilecek kişi, kurum ve toplumu ilgili konu hakkında uyarmak amacıyla yapılmaktadır (Kurnaz, Ercan ve Kestane, 2018: 158). Konuya hile çerçevesinden bakılacak olursa işletmeler her geçen gün çalışanları ve çalışanlarla ilişkili taraflarca önemli kayıplarla karşı karşıya kalmaktadır. Hile kasıtlı bir davranışı içermektedir. Örneğin bir çalışan, işletmeden nakit para, stok, demirbaş vb. varlıkları çalabilmekte ya da üçüncü taraflarla ilişki kurarak rüşvet alabilmektedir. Diğer taraftan finansal tablo hileleri günümüzde son derece ciddi bir problem olarak karşımıza çıkmaktadır. Söz 
konusu hile üst yönetim tarafından gerçekleştirilen bir hile türüdür. Buradaki amaç işletmenin mevcut finansal durumunu amaca göre olduğundan fazla ya da az göstermek için yapılan davranışlar bütünü olarak dikkat çekmektedir. Bu hile türünün gerçekleşmesi ile yatırımcılar, kredi verenler ve devlet önemli ölçüde zarar görmektedir. Özellikle son yıllarda ortaya çıkmış olan Enron skandalı üst yönetim tarafından gerçekleştirilen hile olayına en somut örnektir (Bozkurt, 2016: 64-65).

Suistimal İnceleme Uzmanları Derneği'nin (ACFE) 2018 yılında yayınlamış olduğu "Mesleki Dolandırıcılık Üzerine Küresel Çalışma" adlı raporda "varlıkların kötüye kullanılması" en yaygın gerçekleşen buna karşın en az maliyetli suistimal çeşiti olarak ortaya çıkmıştır. 2690 vakada vakaların \%89'u varlıkların kötüye kullanılması şeklinde sonuçlanmış ve vaka başına ortalama 114 bin dolarlık maliyete yol açmıştır. Diğer taraftan "finansal tablo suistimalleri" ise en az ortaya çıkan fakat en çok maliyete neden olan suistimal türü olarak belirtilmiştir. 2690 vakada vakaların \%10'u finansal tablo suistimali şeklinde sonuçlanmış ortalama vaka başına 800 bin dolarlık maliyete yol açtı̆̆ belirtilmiştir. Söz konusu raporda bilgi ifşasının önemine de değinilmiştir. Tablo 1'de hile davranışını raporlayan kişiler hakkındadır. Tablo 1'de görüleceği üzere hile eyleminin ortaya çıkarılmasında en yüksek pay çalş̧anlara aittir. Ek olarak Tablo 2'de hile eyleminin raporlanma biçimi yer almaktadır. İlgili raporda herhangi bir raporlama biçimi kullanılmadığında bilgi ifşasını yapan kişilerin $\% 32$ 'si doğrudan denetçiye, $\% 15$ 'i yöneticiye, $\% 13$ 'ü hile araştırma ekibine, $\% 12$ 'si iş arkadaşına, \%10'u ise iç denetçiye yaptıkları belirtilmiştir. İstatistiklerden de anlaşılacağı üzere bilgi ifşası hile davranışı gibi önemli maliyetlere yol açan durumların tespit edilmesinde önemli bir rol oynamaktadır.

Tablo 1. Hileyi Raporlayan Kişiler

\begin{tabular}{|c|c|}
\hline Raporlayan Kişi & Yüzdesi \\
\hline Çalışan & $\% 53$ \\
\hline Müşteri & $\% 21$ \\
\hline Anonim & $\% 14$ \\
\hline Satıcı & $\% 8$ \\
\hline Diğer & $\% 5$ \\
\hline Rakipler & $\% 3$ \\
\hline Sahip / Hissedar & $\% 2$ \\
\hline
\end{tabular}

Tablo 2. Hilenin Raporlanma Biçimi

\begin{tabular}{|c|c|}
\hline Raporlama Biçimi & Yüzdesi \\
\hline Telefon & $\% 42$ \\
\hline E-mail & $\% 26$ \\
\hline Web tabanından & $\% 23$ \\
\hline Mektup & $\% 16$ \\
\hline Diğer & $\% 9$ \\
\hline Fax & $\% 1$ \\
\hline \multicolumn{2}{|c}{} \\
\hline
\end{tabular}

$\mathrm{Bu}$ bilgiler 1şığında bir işletmenin bilgi ifşasının etkin bir şekilde gerçekleştirebilmesi için uygun bir organizasyon ortamını hazırlaması gerekmektedir. Ek olarak işletmenin gerek çalışanları gerekse ilişkili diğer kişi ve kurumları cesaretlendirecek bir misyona sahip olması bilgi ifşasının 
amacına uygun olarak gerçekleşmesine önemli katkı sağlayacaktır. Etkin bir bilgi ifşası ortamının oluşturulmasıyla işletme hem çalışanlar arasındaki dürüst iletişimi güçlendirmiş olacak hem de fonksiyonel denetim ve kontrol faaliyetlerinin etkinliğine katkı sağlayacaktır (Kurnaz, Ercan ve Kestane, 2018: 165).

\section{BİLGİ İFŞASINA YÖNELIK LITTERATÜR ÇALIŞMASI}

Bilgi ifşasına yönelik literatürde yer alan çalışmalar incelendiğinde çok sayıda çalışmanın yer aldığı görülmektedir. Bu çalışmalardan bazıları Tablo 3'de belirtildiği gibidir.

Tablo 3. Bilgi İfşasına Yönelik Yapılan Çalışmalar

\begin{tabular}{|c|c|}
\hline Çalışmalar & Bulgular \\
\hline Miceli ve Near (1992) & $\begin{array}{l}\text { Bilgi ifşasında bulunan çalışanların iş kaybı, maaş kaybı, yetki kısıtlaması, } \\
\text { mobbing vb. gibi olumsuz durumlarla karşı karșıya kaldıklarını ortaya çıkarmıștır. }\end{array}$ \\
\hline Hooks ve diğ. (1994) & $\begin{array}{l}\text { Bilgi ifşasının finansal tablo hilelerinin tespit edilmesi ve önlenmesinde önemli } \\
\text { bir iç kontrol mekanizması olacağını ifade etmiștir. }\end{array}$ \\
\hline Near ve Miceli (1995) & $\begin{array}{l}\text { Etkin bilgi ifşasına yönelik bir model oluşturulmuştur. Kuruluşların bilgi ifşasına } \\
\text { yönelik destekleyici bir politika oluşturmaları tavsiye edilmiş diğer taraftan bilgi } \\
\text { ifşasını yapan kişileri koruyucu bir bakış açısının da organizasyonda yer alması } \\
\text { gerektiğini aksi halde bilgi ifşasının gerçekleşme olasılığının azaldığını öne } \\
\text { sürmüşlerdir. }\end{array}$ \\
\hline King (1997) & $\begin{array}{l}\text { Bilgi ifşasından kaçınmanın önemli bir nedeninin ilgili çalışma arkadaşını ifşa } \\
\text { etmenin kişinin kendisinde sadakatsizlik, ihanet duygusu gibi olumsuz duygular } \\
\text { uyandıracağını tespit etmiştir. }\end{array}$ \\
\hline Miceli ve diğ. (1999) & $\begin{array}{l}\text { Federal hükümetteki bilgi uçuranların \%17-38'inin misilleme yaşadığını tespit } \\
\text { etmiştir. }\end{array}$ \\
\hline $\begin{array}{l}\text { Bayraktaroğlu ve diğ. } \\
(2005)\end{array}$ & $\begin{array}{l}\text { Etik eğitiminin yükseköğretimdeki yeri ile ilgili yaptıkları çalışmada diğer } \\
\text { ülkelere kıyasla Türkiye'de yükseköğretimde etik eğitiminin yeterli düzeyde ele } \\
\text { alınmadığı tespit edilmiştir. }\end{array}$ \\
\hline $\begin{array}{l}\text { Mesmer-Magnus ve } \\
\text { Viswesvaran (2005) }\end{array}$ & $\begin{array}{l}\text { Bilgi ifşası yapanların, işte iyi performans gösteren, daha yüksek eğitimli, daha } \\
\text { yüksek pozisyonlara sahip, ahlaki akıl yürütme testlerinde daha yüksek puan alan } \\
\text { ve bilgi ifşasının etik olmanın bir gerekliliği olarak değerlendiren kişiler olduğu } \\
\text { sonucuna varmıştır. }\end{array}$ \\
\hline $\begin{array}{l}\text { Xu ve Ziegenfuss } \\
(2008)\end{array}$ & $\begin{array}{l}\text { İç denetçilere yapılan çalışmada iç denetçilerin kendilerine sürekli istihdam } \\
\text { garantisi ve önemli miktarda nakit ödül vb. gibi finansal ve finansal olmayan } \\
\text { teşvikler sağlanması durumunda bilgi ifşasını yapmaya daha istekli olduklarını } \\
\text { ortaya çıkarmıştır. }\end{array}$ \\
\hline $\begin{array}{l}\text { Eweie ve Brunton } \\
(2009)\end{array}$ & $\begin{array}{l}\text { Endonezya'da işletme öğrencileri üzerinde cinsiyet, yaş ve iş tecrübesinin karar } \\
\text { verme üzerindeki etkilerinin olup olmadıklarını araştırdıkları çalışmada } \\
\text { bayanların, erkeklere göre etik konusunda daha duyarlı oldukları ortaya çıkmıştır. }\end{array}$ \\
\hline $\begin{array}{l}\text { Lau, Choe ve Ramly } \\
\text { (2009) }\end{array}$ & $\begin{array}{l}\text { Geleceğin liderleri olarak görülen öğrencilerin etik uyumlarının araştırıldığı } \\
\text { çalıșmada kızların erkeklere göre daha etik davrandıkları ortaya çıkmıştır. }\end{array}$ \\
\hline
\end{tabular}




\begin{tabular}{|c|c|}
\hline Pope ve Lee (2013) & $\begin{array}{l}\text { Yarı zamanlı olarak çalışan yüksek lisans öğrencilerine yönelik yapılan çalışmada } \\
\text { yıllık maaşların \%20'sine varan bir finansal ödül durumunda bilgi ifşasını } \\
\text { yönetime bildireceklerini ifade etmişlerdir. }\end{array}$ \\
\hline $\begin{array}{lll}\text { Akın } & \text { ve } & \text { Özdaşlı } \\
(2014) & & \end{array}$ & $\begin{array}{l}\text { Muhasebe meslek mensupları ile meslek yüksekokulu öğrencilerinin etik } \\
\text { kavramının algılanmasına yönelik yapılan çalşsmada muhasebe eğitimi alan } \\
\text { öğrencilerin muhasebe mesleğini icra eden meslek mensuplarına kıyasla dürüstlük } \\
\text { ve șeffaflık ilkelerinin meslek mensupları tarafından daha fazla ihlal edildiğini } \\
\text { düşündükleri tespit edilmiştir. }\end{array}$ \\
\hline O’Leary (2014) & $\begin{array}{l}\text { Organizasyonun yasa ve etik dışı politika ve kararlarına karşı çıkan kamu } \\
\text { çalışanlarının iş arkadaşlarından, denetçilerden ve yöneticilerinden tepki ile } \\
\text { karşılaştıklarını ortaya çıkarmıştır. }\end{array}$ \\
\hline Alkan (2015) & $\begin{array}{l}\text { Geleceğin muhasebe meslek mensubu adayları olan Muhasebe ve Vergi } \\
\text { Uygulamaları Programı öğrencilerinin etik değerlerini belirlemeye yönelik } \\
\text { yapılan çalışmada kız ögrencilerin etik algı düzeylerinin erkek öğrencilere göre } \\
\text { daha yüksek olduğu, yaş faktörünün etik algı düzeyini etkilediğini, öğrenim } \\
\text { görülen sınıfın ise etik algısını etkilemediği ek olarak gelir düzeyinin öğrencilerin } \\
\text { etik algısında farklılığa neden olduğu tespit edilmiştir. }\end{array}$ \\
\hline $\begin{array}{l}\text { Daştan, Bellikli ve } \\
\text { Bayraktar (2015) }\end{array}$ & $\begin{array}{l}\text { Karadeniz Teknik Üniversitesi-İktisadi ve İdari Bilimler Fakültesi, İşletme- } \\
\text { Maliye ve İktisat bölümleri, dördüncü sınıf öğrencilerine etik, etik ikilem, etik } \\
\text { karar ve muhasebe meslek etiği eğitimi konularında farkındalık düzeylerini } \\
\text { araştırmak amacıyla yapılan çalışmada alınan muhasebe eğitiminin kalite } \\
\text { düzeyinin, mesleki faaliyetlerde etik tutum ve davranışların belirleyicisi } \\
\text { konumunda olduğu, kişisel çlkarların ön planda tutulmasının etik dışı davranışlara } \\
\text { neden olabileceği ek olarak cinsiyet, öğrenim görülen bölüm ve gelecekte } \\
\text { muhasebe mesleğini tercih etme değişkenleri açısından etik değerlere bakışta } \\
\text { farklılıkların oluştuğu tespit edilmiştir. }\end{array}$ \\
\hline $\begin{array}{l}\text { Miller ve Thomas } \\
(2015)\end{array}$ & $\begin{array}{l}\text { Bilgi ifşasını gerçekleştirecek kişinin kendinden daha üstün pozisyonda olan bir } \\
\text { kişinin sergilemiş olduğu yasa ve etik dışı davranışlar hakkında bilgi ifşasında } \\
\text { bulunmaya daha az istekli olduğu sonucuna ulaşmışlardır. }\end{array}$ \\
\hline $\begin{array}{l}\text { Gülmez, Kıllı ve Öz } \\
\text { (2016) }\end{array}$ & $\begin{array}{l}\text { Osmaniye Korkut Ata Üniversitesinde öğrenim gören ve çeşitli muhasebe } \\
\text { derslerini alan Osmaniye Meslek Yüksekokulu (İşletme ve Muhasebe ve Vergi } \\
\text { Uygulamaları programı) ön lisans öğrencileri ile İktisadi ve İdari Bilimler } \\
\text { Fakültesi (İşletme, Yönetim Bilişim Sistemleri, İktisat, Siyaset Bilimi ve Kamu } \\
\text { Yönetimi ve Uluslararası Ticaret ve Lojistik bölümü) lisans öğrencilerinin } \\
\text { muhasebe meslek etiğine bakış açılarını araştırmak amacıyla yapılan çalışmada } \\
\text { meslek etiği ve etik ilkelere bağlllık kapsamında kız öğrencilerin erkek öğrencilere } \\
\text { göre daha duyarlı olduğu, meslek etiği dersinin ilgili bölüm müfredatlarında yer } \\
\text { almasının faydalı olacağı, etik eğitimi ile etik ilkelere bağlılığın artacağı tespit } \\
\text { edilmiştir. }\end{array}$ \\
\hline
\end{tabular}

\section{ARASTTIRMANIN AMACI VE YÖNTEMI}

Bu çalışmada, geleceğin muhasebe meslek mensubu adayları olan İktisadi ve İdari Bilimler Fakültesi İşletme Bölümü lisans öğrencileri, yüksek lisans öğrencileri ve Ticaret Liseleri Muhasebe Bölümü öğrencilerinin bilgi ifş̧asına ilişkin görüşlerinin değerlendirilmesi amaçlanmaktadır. $\mathrm{Bu}$ amaca dönük, çalışmada veri toplama aracı olarak, literatür taraması sonucunda Alleyne, WeekesMarshall ve Arthur (2012); Park, Rehg ve Lee (2005) ve Mustapha ve Siaw (2012) çalışmasında uygulanan anketler temel alınmıştır. Veri toplama aracı olarak kullanılan anket likert ölçeği şeklinde hazırlanmış olup katılımcıların ifadeleri, hiç katılmıyorsa "1", tamamen katılıyorsa "5" puan aralığında yer alan değerlendirmeler üzerinden anlamlandırılmıştır. Anket uygulaması İktisadi ve 
İdari Bilimler Fakültesi İşletme Bölümü lisans ve yüksek lisans öğrencileri ve Ticaret Lisesi öğrencileri olmak üzere, 2020 Aralık ve Ocak 2021 döneminde, 250 öğrenci üzerinde gerçekleştirilmiştir. Katılımcılardan elde edilen veriler SPSS 22.0 (Statistical Package for the Social Sciences) programı kullanılarak analiz edilmiştir. Analizlerde öncelikle demografik göstergelere ilişkin değerlendirmeler yapılmıştır. Akabinde çalışmada veriler, parametrik testlerin varsayımları karşılandığı için parametrik testler ile analiz edilmiştir.

\subsection{Araştırma Sonuçları}

\subsubsection{Demografik Bulgular}

Çalışmada elde edilen demografik bulgular tablo 4'de belirtildiği gibidir. Buna göre ankete cevap veren katılımcıların $\% 51,2$ 'si kadın, $\% 48,8$ 'i erkektir. Katılımcıların yaş dağılımları incelendiğinde ağırlıklı olarak 20-24 yaş aralığında katılımcılar olduğu tespit edilmiştir. Katılımcıların \%21,6 lise, \%77,6 lisans ve \%0,8 lisansüstü öğrencilerden oluşmaktadır. Katılımcıların aile içi iliş̧ki seviyeleri değerlendirildiğinde \%70,4'ü aileleri ile ilişkilerini iyi seviyede tanımlarken, \%27,6'sı aileleri ile ilişkilerini orta seviyede tanımlamaktadır. Bununla birlikte aile içi gelir dağılımına bakıldığında \%10'nun yüksek gruba ,\% 84,8'nin orta gruba ve \% 5,2'sinin düşük gruba dahil olduğu görülmektedir.

Tablo 4. Demografik Göstergeler

\begin{tabular}{|c|c|c|}
\hline & $\mathbf{n}$ & $\%$ \\
\hline \multicolumn{3}{|c|}{ Cinsiyet } \\
\hline Kadın & 128 & 51,2 \\
\hline Erkek & 122 & 48,8 \\
\hline \multicolumn{3}{|c|}{ Eğitim Durumu } \\
\hline Lise Seviyesi & 54 & 21,6 \\
\hline Lisans Seviyesi & 194 & 77,6 \\
\hline Lisansüstü Seviyesi & 2 & 0,8 \\
\hline \multicolumn{3}{|c|}{ Aile İçi İlişki Seviyeleri } \\
\hline Kötü & 5 & 2,0 \\
\hline Orta & 69 & 27,6 \\
\hline İyi & 176 & 70,4 \\
\hline \multicolumn{3}{|c|}{ Aile İçi Gelir Dağılımı } \\
\hline Düşük & 13 & 5,2 \\
\hline Orta & 212 & 84,8 \\
\hline Yüksek & 25 & 10 \\
\hline
\end{tabular}

\subsubsection{Bağımsız Örneklem t-Testi Sonuçları}

Değişkenler arasında anlamlı farklılığın tespit edilmesinde ikili gruplar için bağımsız örneklem t-testi uygulanmıştır. Katılımcıların cinsiyeti ile katılımcıların Bilgi İfşşasına İlişkin Görüşlerini içeren ifadeler arasındaki anlamlı farklılığı test etmek için oluşturulan hipotez şu şekildedir;

$\mathrm{H} 0=$ Katılımcıların Bilgi İfşasına İlişkin Görüşleri ile Katılımcı Cinsiyeti arasında anlamlı bir farklılık yoktur.

H1= Katılımcıların Bilgi İfşasına İlişkin Görüşleri ile Katılımcı Cinsiyeti arasında anlamlı bir farklılık vardır.

Analiz sonucunda elde edilen değerler Tablo 5 ve Tablo 6'da belirtildiği gibidir. 
Tablo 5. Grup İstatistik Değerleri

\begin{tabular}{|c|c|c|c|c|}
\hline İfadeler & Cinsiyet & Ortalama & $\begin{array}{l}\text { Standart } \\
\text { Sapma }\end{array}$ & Standart Hata \\
\hline \multirow[t]{2}{*}{ İhbar yapan kişi kahramandır } & Erkek & 3,2787 & 1,18714 &, 10748 \\
\hline & Kadın & 3,3750 & 1,08679 & 09606 \\
\hline \multirow[t]{2}{*}{ İhbarcılık, ahlaki bir davranıştır } & Erkek & 3,8607 & 1,03904 & 09407 \\
\hline & Kadın & 3,7813 & 1,01901 & 09007 \\
\hline \multirow[t]{2}{*}{ İhbarcılık, profesyonel olmanın bir gereğidir } & Erkek & 3,2951 & 1,19702 &, 10837 \\
\hline & Kadın & 3,1797 & 1,12546 & 09948 \\
\hline \multirow{2}{*}{$\begin{array}{l}\text { Gelecekte kendimi bir muhasebe meslek mensubu olarak hayal } \\
\text { ettiğimde; ahlaki değerler benim için çok önemlidir }\end{array}$} & Erkek & 4,0984 & 1,10154 & 09973 \\
\hline & Kadın & 3,9375 & 1,06298 &, 09395 \\
\hline \multirow[t]{2}{*}{ Sadece zorunlu kaldığımda ihbarcı olmayı tercih ederim } & Erkek & 2,9426 & 1,33793 &, 12113 \\
\hline & Kadın & 3,1953 & 1,25528 &, 11095 \\
\hline \multirow[t]{2}{*}{ İhbar yapan kişi, sorumluluk sahibi bir vatandaştır } & Erkek & 4,0410 & 1,09392 &, 09904 \\
\hline & Kadin & 3,8438 & 1,01514 & 08973 \\
\hline \multirow{2}{*}{$\begin{array}{l}\text { İhbar yapmak; hileyi, sahtekarlığı, yanlış yönetmeyi ve } \\
\text { yozlaşmayı engeller }\end{array}$} & Erkek & 3,9754 & 1,02420 & 09273 \\
\hline & Kadın & 3,7188 & 1,10073 & 09729 \\
\hline \multirow[t]{2}{*}{ İhbarcılık, ahlaki davranışları teşvik eder } & Erkek & 3,8770 & ,94106 &, 08520 \\
\hline & Kadın & 3,6875 & ,98612 & 08716 \\
\hline \multirow{2}{*}{$\begin{array}{l}\text { İşletmelerde meydana gelen usulsüzlük, haksızlık, } \\
\text { dolandırıcılık gibi ahlaki olmayan bir davranış; eğer başkalarına } \\
\text { zarar veriyorsa, bu durumu gerekli mercilere ihbar ederim }\end{array}$} & Erkek & 4,2623 & 86055 & 07791 \\
\hline & Kadın & 3,9453 & 1,01414 & 08964 \\
\hline \multirow{2}{*}{$\begin{array}{l}\text { Sadece işletmeye etkisi çok büyükse, suç içeren bir davranışı } \\
\text { ihbar etmeyi tercih ederim }\end{array}$} & Erkek & 3,2459 & 1,28765 & ,11658 \\
\hline & Kadın & 3,2344 & 1,14661 & 10135 \\
\hline \multirow[t]{2}{*}{ İhbarcı olmayı çevremi korumak için tercih ederim } & Erkek & 3,6967 & 1,19149 &, 10787 \\
\hline & Kadın & 3,7578 & ,99405 & 08786 \\
\hline \multirow{2}{*}{$\begin{array}{l}\text { İhbar etmeyi, ancak kendimi güvende hissedersem tercih } \\
\text { ederim }\end{array}$} & Erkek & 3,3443 & 1,22488 & 11090 \\
\hline & Kadın & 3,2344 & 1,12582 & 09951 \\
\hline \multirow{2}{*}{$\begin{array}{l}\text { Sadece başkaları da ihbar ettiğinde ve sonuçları gördüğümde } \\
\text { ihbar etmeyi tercih ederim }\end{array}$} & Erkek & 2,7459 & 1,18225 & 10704 \\
\hline & Kadın & 2,9141 & 1,12961 & ,09984 \\
\hline \multirow{2}{*}{$\begin{array}{l}\text { İhbarcılık, kamu yararını (kamu etkinliğini) artırmaya yardımcı } \\
\text { olur }\end{array}$} & Erkek & 3,9180 & ,94990 &, 08600 \\
\hline & Kadın & 3,7656 & ,89164 & 07881 \\
\hline \multirow[t]{2}{*}{ İhbarcılık, yolsuzlukları önlemeye yardımcı olur. } & Erkek & 4,0246 &, 95747 & 08669 \\
\hline & Kadın & 3,7188 & 1,07906 & 09538 \\
\hline \multirow[t]{2}{*}{ İhbar etmeyi düşünüyorsam hukuki yollara başvururum } & Erkek & 1,2541 &, 43715 & 03958 \\
\hline & Kadın & 1,2031 & ,40391 &, 03570 \\
\hline \multirow[t]{2}{*}{ İhbar etmeyi düşünüyorsam sosyal ağlarda paylaşırım } & Erkek & 1,6148 & ,48866 & 04424 \\
\hline & Kadın & 1,6563 & ,47683 & 04215 \\
\hline \multirow{2}{*}{$\begin{array}{l}\text { Îhbar etmeyi düşünüyorsam kurum içinde yönetime ihbarda } \\
\text { bulunurum }\end{array}$} & Erkek & 1,3279 & ,47137 &, 04268 \\
\hline & Kadın & 1,2734 & ,44747 & 03955 \\
\hline \multirow{2}{*}{$\begin{array}{l}\text { İhbar etmeyi düşünüyorsam kurum içinde mesai arkadaşlarımla } \\
\text { paylaşırım }\end{array}$} & Erkek & 1,5820 & ,49527 &, 04484 \\
\hline & Kadın & 1,5703 & ,49698 & 04393 \\
\hline & Erkek & 1,5246 &, 50145 & 04540 \\
\hline kullanırım & Kadın & 1,5625 & ,49803 & ,04402 \\
\hline İhbar etmeyi düşünmüyorsam kendime zararı olacağını & Erkek & 1,6557 & ,49411 & 04473 \\
\hline düşündüğüm için çekinirim ve ihbar etmem & Kadın & 1,5859 & ,49449 & 04371 \\
\hline İhbar etmeyi düșünmüyorsam ișten atılmaktan korktuğum için & Erkek & 1,6557 & 47709 & 04319 \\
\hline ihbar etmem & Kadın & 1,6016 & ,49150 &, 04344 \\
\hline İhbar etmeyi düşünmüyorsam ayılanmaktan ve ispiyoncu & Erkek & 1,6721 & ,47137 & 04268 \\
\hline olarak görülmekten korktuğum için ihbar etmem & Kadın & 1,7109 & 45511 & 04023 \\
\hline İhbar etmeyi düşünmüyorsam ihbar ettiğim kişi ya da kişilerin & Erkek & 1,6311 & ,48448 & 04386 \\
\hline $\begin{array}{l}\text { yaptırım gücünden ve misillemeden korktuğum için ihbar } \\
\text { etmem }\end{array}$ & Kadın & 1,6406 & ,48170 & 04258 \\
\hline İhbar etmeyi düşünmüyorsam başkalarının tepki vermesini & Erkek & 1,8934 & ,30982 & ,02805 \\
\hline & Kadın & 1,8594 & ,34900 & 03085 \\
\hline İhbar etmeyi düşünmüyorsam ihbar ettiğim takdirde bile & Erkek & 1,4754 &, 50145 &, 04540 \\
\hline $\begin{array}{l}\text { herhangi bir şeyin düzelmeyeceğini düşündüğüm için ihbar } \\
\text { etmem }\end{array}$ & Kadın & 1,5078 & ,50190 & 04436 \\
\hline İhbar etmeyi düşünmüyorsam kişilik yapım gereği sessiz & Erkek & 1,9262 & ,26247 &, 02376 \\
\hline kalırım (ihbar etmem) & Kadın & 1,8906 & ,31334 &, 02770 \\
\hline
\end{tabular}


Tablo 6. Bağımsız T testi Sonuçları

\begin{tabular}{|c|c|c|c|c|c|c|}
\hline & \multicolumn{3}{|c|}{ Levene's Test for Equality of Variances } & \multicolumn{3}{|c|}{ t-test for Equality of Means } \\
\hline & & $\mathbf{F}$ & Sig. & t & Df & Sig \\
\hline \multirow{2}{*}{ İhbar yapan kişi kahramandır } & Eşit Dağılım & ,750 &, 387 &,- 670 & 248 &, 504 \\
\hline & Eșit Olmayan Dağılım & & & -668 & 243,491 & 505 \\
\hline \multirow[t]{2}{*}{ İhbarcılık, ahlaki bir davranıştır } & Eşit Dağılım & ,206 &, 650 & 610 & 248 &, 542 \\
\hline & Eşit Olmayan Dağgllım & & & ,610 & 246,870 &, 543 \\
\hline \multirow{2}{*}{$\begin{array}{l}\text { İhbarcilık, profesyonel olmanın bir } \\
\text { gereğidir }\end{array}$} & Eşit Dağıllım & ,612 & ,435 & ,786 & 248 &, 433 \\
\hline & Eşit Olmayan Dağılım & & & ,784 & 245,053 & ,434 \\
\hline \multirow{2}{*}{$\begin{array}{l}\text { Gelecekte kendimi bir muhasebe } \\
\text { meslek mensubu olarak hayal } \\
\text { ettiğimde; ahlaki değerler benim için } \\
\text { çok önemlidir }\end{array}$} & Eşit Dağılım & 007 & ,933 & 1,175 & 248 & 241 \\
\hline & Eşit Olmayan Dağılım & & & 1,174 & 246,271 & 242 \\
\hline \multirow{2}{*}{$\begin{array}{l}\text { Sadece zorunlu kaldığımda ihbarcı } \\
\text { olmayı tercih ederim }\end{array}$} & Eșit Dağllım & 054 &, 816 & $-1,541$ & 248 & ,125 \\
\hline & Eşit Olmayan Dağglım & & & $-1,538$ & 244,940 & ,125 \\
\hline \multirow{2}{*}{$\begin{array}{l}\text { İhbar yapan kişi, sorumluluk sahibi } \\
\text { bir vatandaştır }\end{array}$} & Eşit Dağılım & ,006 & ,938 & 1,479 & 248 &, 141 \\
\hline & Eşit Olmayan Dağglım & & & 1,476 & 244,325 & ,141 \\
\hline \multirow{2}{*}{$\begin{array}{l}\text { İhbar yapmak; hileyi, sahtekârlığı, } \\
\text { yanlış yönetmeyi ve yozlaşmayı } \\
\text { engeller }\end{array}$} & Eşit Dağıllım & 2,908 & 189 & 1,906 & 248 &, $050 * *$ \\
\hline & Eşit Olmayan Dağılım & & & 1,910 & 247,859 &, $050 * *$ \\
\hline \multirow{2}{*}{$\begin{array}{l}\text { İhbarcılık, ahlaki davranışları teşvik } \\
\text { eder }\end{array}$} & Eşit Dağılım &, 584 & ,446 & 1,553 & 248 &, 122 \\
\hline & Eșit Olmayan Dağglım & & & 1,555 & 247,999 &, 121 \\
\hline \multirow[b]{2}{*}{$\begin{array}{l}\text { İssletmelerde meydana gelen } \\
\text { usulsüzlük, haksızlık, dolandırıcılık } \\
\text { gibi ahlaki olmayan bir davranış; } \\
\text { eğer başkalarına zarar veriyorsa, bu } \\
\text { durumu gerekli mercilere ihbar } \\
\text { ederim }\end{array}$} & Eşit Dağılım & 2,524 &, 113 & 2,659 & 248 &, $008^{* *}$ \\
\hline & Eşit Olmayan Dağılım & & & 2,669 & 244,755 &, $008 * *$ \\
\hline \multirow{2}{*}{$\begin{array}{l}\text { Sadece } \\
\text { işletmeye etkisi cok } \\
\text { büyükse, suç içeren bir davranışı } \\
\text { ihbar etmeyi tercih ederim }\end{array}$} & Eşit Dağllım & 3,521 &, 062 & 075 & 248 &, 940 \\
\hline & Eşit Olmayan Dağılım & & & ,075 & 241,555 & ,941 \\
\hline \multirow{2}{*}{$\begin{array}{l}\text { İhbarcı olmayı çevremi korumak } \\
\text { için tercih ederim }\end{array}$} & Eşit Dağılım & 3,805 & 052 &,- 441 & 248 & 660 \\
\hline & Eşit Olmayan Dağglım & & &,- 439 & 235,886 & ,661 \\
\hline \multirow{2}{*}{$\begin{array}{l}\text { İhbar etmeyi, ancak kendimi } \\
\text { güvende hissedersem tercih ederim }\end{array}$} & Eşit Dağılım & 1,588 & ,209 & ,739 & 248 & ,461 \\
\hline & Eşit Olmayan Dağglım & & & ,738 & 243,743 & ,462 \\
\hline \multirow{2}{*}{$\begin{array}{l}\text { Sadece başkaları da ihbar ettiğinde } \\
\text { ve sonuçları gördüğümde ihbar } \\
\text { etmeyi tercih ederim }\end{array}$} & Eşit Dağılım & 1,800 & 181 & $-1,150$ & 248 & 251 \\
\hline & Eşit Olmayan Dağılım & & & $-1,149$ & 245,844 & ,252 \\
\hline \multirow{2}{*}{$\begin{array}{l}\text { İhbarcılık, kamu yararını (kamu } \\
\text { etkinliğini) artırmaya yardımcı olur }\end{array}$} & Eşit Dağılım &, 066 & ,798 & 1,309 & 248 & 192 \\
\hline & Eşit Olmayan Dağglım & & & 1,307 & 244,965 & ,193 \\
\hline \multirow{2}{*}{$\begin{array}{l}\text { İhbarcılık, yolsuzlukları önlemeye } \\
\text { yardımcı olur. }\end{array}$} & Eşit Dağılım & 4,751 &, 530 & 2,366 & 248 &, $019 * *$ \\
\hline & Eşit Olmayan Dağı̆lım & & & 2,373 & 246,753 &, $019 * *$ \\
\hline \multirow{2}{*}{$\begin{array}{l}\text { İhbar etmeyi düşünüyorsam hukuki } \\
\text { yollara başvururum }\end{array}$} & Eşit Dağılım & 3,678 &, 056 & ,958 & 248 & ,339 \\
\hline & Eşit Olmayan Dağılım & & & ,956 & 244,066 & ,340 \\
\hline \multirow{2}{*}{$\begin{array}{l}\text { İhbar etmeyi düşünüyorsam sosyal } \\
\text { ağlarda paylaşırım }\end{array}$} & Eşit Dağılım & 1,805 & ,180 &,- 680 & 248 & ,497 \\
\hline & Eşit Olmayan Dağglım & & &,- 679 & 246,696 & ,498 \\
\hline \multirow{2}{*}{$\begin{array}{l}\text { İhbar etmeyi düşünüyorsam kurum } \\
\text { içinde yönetime ihbarda bulunurum }\end{array}$} & Eşit Dağılım & 3,471 & 064 & ,937 & 248 &, 350 \\
\hline & Eşit Olmayan Dağılım & & & ,935 & 245,539 &, 350 \\
\hline \multirow{2}{*}{$\begin{array}{l}\text { İhbar etmeyi düşünüyorsam kurum } \\
\text { içinde mesai arkadaşlarımla } \\
\text { paylaşırım }\end{array}$} & Eşit Dağllım &, 138 & ,711 & ,186 & 248 & $\begin{array}{l}, 853 \\
\end{array}$ \\
\hline & Eşit Olmayan Dağılım & & & ,186 & 247,504 & ,853 \\
\hline İhbar etmeyi düşünüyorsam kurum & Eşit Dağılım & 1,194 & ,276 &,- 600 & 248 &, 549 \\
\hline içinde resmi prosedürleri kullanırım & Eșit Olmayan Dağı̆ım & & &,- 599 & 247,250 &, 549 \\
\hline İhbar etmeyi düşünmüyorsam & Eșit Dağılım & 1,864 & ,173 & 1,116 & 248 &, 265 \\
\hline $\begin{array}{l}\text { kendime zararı olacağını } \\
\text { düşündüğüm için çekinirim ve ihbar } \\
\text { etmem }\end{array}$ & Eşit Olmayan Dağılım & & & 1,116 & 247,444 & 265 \\
\hline İhbar etmeyi düşünmüyorsam işten & Eşit Dağılım & 3,058 & 082 & 884 & 248 & ,378 \\
\hline $\begin{array}{l}\text { atılmaktan korktuğum için ihbar } \\
\text { etmem }\end{array}$ & Eşit Olmayan Dağılım & & & $\begin{array}{ll}, 884 \\
\end{array}$ & 247,916 & 377 \\
\hline $\begin{array}{lll}\text { İhbar } & \text { etmeyi } & \text { düșünmüyorsam }\end{array}$ & Eşit Dağılım & 1,740 & ,188 &,- 662 & 248 & ,508 \\
\hline $\begin{array}{l}\text { ayıplanmaktan ve ispiyoncu olarak } \\
\text { görülmekten korktuğum için ihbar } \\
\text { etmem }\end{array}$ & Eşit Olmayan Dağılım & & &,- 662 & 246,292 &, 509 \\
\hline İhbar etmeyi düşünmüyorsam ihbar & Eşit Dağılım & 096 & 757 &,- 155 & 248 & 877 \\
\hline ettiğim kişi ya da kişilerin yaptırım & Eşit Olmayan Dağglım & & &,- 155 & 247,280 & ,877 \\
\hline
\end{tabular}




\begin{tabular}{|c|c|c|c|c|c|c|}
\hline \multicolumn{7}{|l|}{$\begin{array}{l}\text { gücünden ve } \quad \text { misillemeden } \\
\text { korktuğum için ihbar etmem }\end{array}$} \\
\hline \multirow{2}{*}{$\begin{array}{l}\text { İhbar etmeyi düşünmüyorsam } \\
\text { başkalarının tepki vermesini } \\
\text { beklemeyi tercih ettiğim için ihbar } \\
\text { etmem }\end{array}$} & Eşit Dağılım & 2,684 & ,103 &, 815 & 248 &, 416 \\
\hline & Eşit Olmayan Dağılım & & & 817 & 246,770 & ,415 \\
\hline \multirow{2}{*}{$\begin{array}{l}\text { İhbar etmeyi düşünmüyorsam ihbar } \\
\text { ettiğim takdirde bile herhangi bir } \\
\text { şeyin düzelmeyeceğini düşündüğüm } \\
\text { için ihbar etmem }\end{array}$} & Eşit Dağılım & 225 & ,636 &,- 510 & 248 &, 610 \\
\hline & Eşit Olmayan Dağılım & & &,- 510 & 247,446 & ,610 \\
\hline \multirow{2}{*}{$\begin{array}{l}\text { İhbar etmeyi düşünmüyorsam kişilik } \\
\text { yapım gereği sessiz kalırım (ihbar } \\
\text { etmem) }\end{array}$} & Eşit Dağ $11 \mathrm{~m}$ & 3,835 & 051 & ,972 & 248 &, 332 \\
\hline & Eşit Olmayan Dağılım & & & ,976 & 244,016 &, 330 \\
\hline
\end{tabular}

* \%10 anlamlıık düzeyinde anlamlıdır.

Analiz sonuçları değerlendirdiğinde "İhbar yapmak; hileyi, sahtekârlığı, yanlış yönetmeyi ve yozlaşmayı engeller" ifadesine dair görüşlerin cinsiyet açısından farklılık gösterdiği görülmektedir. Buna göre erkek katılımcılar ihbar yapmanın; hileyi, sahtekârlığı, yanlış yönetmeyi ve yozlaşmayı engellediği görüşüne daha fazla sahiptirler. "İşletmelerde meydana gelen usulsüzlük, haksızlık, dolandırıcılık gibi ahlaki olmayan bir davranış; eğer başkalarına zarar veriyorsa, bu durumu gerekli mercilere ihbar ederim" ifadesi de erkek katılımcılar tarafından daha fazla inanılan görüş olmakla birlikte cinsiyet açısından bu ifadede anlamlı farklılıklar olduğu görülmektedir. Benzer şekilde İhbarcılığın, yolsuzlukları önlemeye yardımcı olacağı görüşü erkek katılımcılar tarafından daha yüksek oranda kabul edilen görüştür. Bilgi ifşsasına ilişkin diğer ifadelerde cinsiyet açısından anlamlı bir farlılık gözlenmemiştir.

\subsubsection{ANOVA Test Sonuçları}

Çalışma kapsamında çoklu gruplar için Tek yönlü varyans analizi (ANOVA) yapılmıştır. Tek yönlü varyans analizinin temel varsayımları, her bir grubun normal dağılım göstermesi ve grupların varyanslarının homojen olması şeklindedir (Kalaycı, 2010). Tek yönlü varyans analizi yapılmadan önce varsayımlar test edilmiştir. Buna göre varyans homojenliği testi sonucunda p değeri 0.05 ten büyük olduğu için varyansların homojen olduğu görülmektedir. Varsayım sağlandığı için varyans analizi kapsamında hipotezler oluşturulmuştur. Bu hipotezler katılımcıların Bilgi İfşasına İlişkin Görüş̧lerini içeren ifadelerin temel demografik göstergeler açısından farklılık gösterip göstermeyeceğinin değerlendirmesini temel almaktadır.

Öncelikle katılımcıların Bilgi İfşasına İlişkin Görüşleri ile eğitim ilişkisi incelenmiştir. Katılımcıların Bilgi İfşasına İlişkin Görüşleri ile Eğitim düzeyleri arasındaki değerlendirme için oluşturulan hipotez şu şekildedir;

H0= Katılımcıların Bilgi İfşasına İlişkin Görüşleri içeren ifadeler ile Katılımcı eğitim düzeyi arasında anlamlı bir farklılık yoktur.

H1= Katılımcıların Bilgi İfşasına İlişkin Görüşleri içeren ifadeler ile Katılımcı eğitim düzeyi arasında anlamlı bir farklılık vardır.

Elde edilen sonuçlar Tablo 7'de belirtildiği gibidir. 
Tablo 7. Anova Testi Sonuçları

\begin{tabular}{|c|c|c|c|c|c|c|}
\hline & & $\begin{array}{l}\text { Kareler } \\
\text { Toplamı }\end{array}$ & sd & $\begin{array}{c}\text { Kareler } \\
\text { Ortalaması }\end{array}$ & $\mathbf{F}$ & Sig. \\
\hline \multirow[t]{3}{*}{ İhbar yapan kişi kahramandır } & $\begin{array}{l}\text { Gruplar } \\
\text { arasinda }\end{array}$ & 4,285 & 2 & 2,142 & 1,670 & , 190 \\
\hline & $\begin{array}{l}\text { Gruplar } \\
\text { İçinde }\end{array}$ & 316,819 & 247 & 1,283 & & \\
\hline & Toplam & 321,104 & 249 & & & \\
\hline \multirow[t]{3}{*}{ İhbarcılık, ahlaki bir davranıştır } & $\begin{array}{l}\text { Gruplar } \\
\text { arasinda }\end{array}$ & 16,915 & 2 & 8,458 & 8,493 &, $000^{*}$ \\
\hline & $\begin{array}{l}\text { Gruplar } \\
\text { İçinde }\end{array}$ & 245,985 & 247 & ,996 & & \\
\hline & Toplam & 262,900 & 249 & & & \\
\hline \multirow[t]{3}{*}{$\begin{array}{l}\text { İhbarcılık, profesyonel olmanın bir } \\
\text { gereğidir }\end{array}$} & $\begin{array}{l}\text { Gruplar } \\
\text { arasinda }\end{array}$ & 20,727 & 2 & 10,364 & 8,143 &, $000 *$ \\
\hline & $\begin{array}{l}\text { Gruplar } \\
\text { İçinde }\end{array}$ & 314,349 & 247 & 1,273 & & \\
\hline & Toplam & 335,076 & 249 & & & \\
\hline \multirow{3}{*}{$\begin{array}{l}\text { Gelecekte kendimi bir muhasebe meslek } \\
\text { mensubu olarak hayal ettiğimde; ahlaki } \\
\text { değerler benim için çok önemlidir }\end{array}$} & $\begin{array}{l}\text { Gruplar } \\
\text { arasinda }\end{array}$ & 35,770 & 2 & 17,885 & 17,245 &, $000^{*}$ \\
\hline & $\begin{array}{l}\text { Gruplar } \\
\text { İçinde }\end{array}$ & 256,166 & 247 & 1,037 & & \\
\hline & Toplam & 291,936 & 249 & & & \\
\hline \multirow[t]{3}{*}{$\begin{array}{l}\text { Sadece zorunlu kaldığımda ihbarcı olmayı } \\
\text { tercih ederim }\end{array}$} & $\begin{array}{l}\text { Gruplar } \\
\text { arasinda }\end{array}$ & 4,704 & 2 & 2,352 & 1,397 & ,249 \\
\hline & $\begin{array}{l}\text { Gruplar } \\
\text { İçinde }\end{array}$ & 416,000 & 247 & 1,684 & & \\
\hline & Toplam & 420,704 & 249 & & & \\
\hline \multirow[t]{3}{*}{$\begin{array}{l}\text { İhbar yapan kişi, sorumluluk sahibi bir } \\
\text { vatandaştır }\end{array}$} & $\begin{array}{l}\text { Gruplar } \\
\text { arasinda }\end{array}$ & 15,684 & 2 & 7,842 & 7,382 &, $001 *$ \\
\hline & $\begin{array}{l}\text { Gruplar } \\
\text { İçinde }\end{array}$ & 262,416 & 247 & 1,062 & & \\
\hline & Toplam & 278,100 & 249 & & & \\
\hline \multirow[t]{3}{*}{$\begin{array}{l}\text { İhbar yapmak; hileyi, sahtekârlığı, yanlış } \\
\text { yönetmeyi ve yozlaşmayı engeller }\end{array}$} & $\begin{array}{l}\text { Gruplar } \\
\text { arasinda }\end{array}$ & 26,629 & 2 & 13,315 & 12,733 &, $000^{*}$ \\
\hline & $\begin{array}{l}\text { Gruplar } \\
\text { İçinde }\end{array}$ & 258,287 & 247 & 1,046 & & \\
\hline & Toplam & 284,916 & 249 & & & \\
\hline \multirow[t]{3}{*}{ İhbarcılık, ahlaki davranışları teşvik eder } & $\begin{array}{l}\text { Gruplar } \\
\text { arasinda }\end{array}$ & 34,882 & 2 & 17,441 & 21,755 &, $000^{*}$ \\
\hline & $\begin{array}{l}\text { Gruplar } \\
\text { İçinde }\end{array}$ & 198,018 & 247 & ,802 & & \\
\hline & Toplam & 232,900 & 249 & & & \\
\hline \multirow{3}{*}{$\begin{array}{l}\text { İşletmelerde meydana gelen usulsüzlük, } \\
\text { haksızlık, dolandırıcılık gibi ahlaki } \\
\text { olmayan bir davranış; eğer başkalarına } \\
\text { zarar veriyorsa, bu durumu gerekli } \\
\text { mercilere ihbar ederim }\end{array}$} & $\begin{array}{l}\text { Gruplar } \\
\text { arasinda }\end{array}$ & 26,498 & 2 & 13,249 & 16,362 &, $000^{*}$ \\
\hline & $\begin{array}{l}\text { Gruplar } \\
\text { İçinde }\end{array}$ & 200,002 & 247 & ,810 & & \\
\hline & Toplam & 226,500 & 249 & & & \\
\hline \multirow{3}{*}{$\begin{array}{l}\text { Sadece işletmeye etkisi çok büyükse, suç } \\
\text { içeren bir davranışı ihbar etmeyi tercih } \\
\text { ederim }\end{array}$} & $\begin{array}{l}\text { Gruplar } \\
\text { arasinda }\end{array}$ & 2,172 & 2 & 1,086 & ,734 & ,481 \\
\hline & $\begin{array}{l}\text { Gruplar } \\
\text { İçinde }\end{array}$ & 365,428 & 247 & 1,479 & & \\
\hline & Toplam & 367,600 & 249 & & & \\
\hline \multirow[t]{3}{*}{$\begin{array}{l}\text { İhbarcı olmayı çevremi korumak için } \\
\text { tercih ederim }\end{array}$} & $\begin{array}{l}\text { Gruplar } \\
\text { arasinda }\end{array}$ & 7,615 & 2 & 3,807 & 3,244 &, $041 *$ \\
\hline & $\begin{array}{l}\text { Gruplar } \\
\text { İçinde }\end{array}$ & 289,889 & 247 & 1,174 & & \\
\hline & Toplam & 297,504 & 249 & & & \\
\hline
\end{tabular}




\begin{tabular}{|c|c|c|c|c|c|c|}
\hline \multirow[t]{3}{*}{$\begin{array}{l}\text { İhbar etmeyi, ancak kendimi güvende } \\
\text { hissedersem tercih ederim }\end{array}$} & $\begin{array}{l}\text { Gruplar } \\
\text { arasinda }\end{array}$ & ,487 & 2 & ,244 & , 176 & ,839 \\
\hline & $\begin{array}{l}\text { Gruplar } \\
\text { İçinde }\end{array}$ & 342,777 & 247 & 1,388 & & \\
\hline & Toplam & 343,264 & 249 & & & \\
\hline \multirow{3}{*}{$\begin{array}{l}\text { Sadece başkaları da ihbar ettiğinde ve } \\
\text { sonuçları gördügüumde ihbar etmeyi tercih } \\
\text { ederim }\end{array}$} & $\begin{array}{l}\text { Gruplar } \\
\text { arasinda }\end{array}$ & 11,605 & 2 & 5,802 & 4,460 & ,013* \\
\hline & $\begin{array}{l}\text { Gruplar } \\
\text { İçinde }\end{array}$ & 321,339 & 247 & 1,301 & & \\
\hline & Toplam & 332,944 & 249 & & & \\
\hline \multirow[t]{3}{*}{$\begin{array}{l}\text { İhbarcılık, } \text { kamu yararını }(\text { kamu } \\
\text { etkinliğini) }\end{array}$} & $\begin{array}{l}\text { Gruplar } \\
\text { arasinda }\end{array}$ & 23,230 & 2 & 11,615 & 15,230 & ,000* \\
\hline & $\begin{array}{l}\text { Gruplar } \\
\text { İçinde }\end{array}$ & 188,370 & 247 & ,763 & & \\
\hline & Toplam & 211,600 & 249 & & & \\
\hline \multirow[t]{3}{*}{$\begin{array}{l}\text { İhbarcılık, yolsuzlukları önlemeye } \\
\text { yardımcı olur. }\end{array}$} & $\begin{array}{c}\text { Gruplar } \\
\text { arasinda }\end{array}$ & 17,057 & 2 & 8,528 & 8,508 & ,000* \\
\hline & $\begin{array}{l}\text { Gruplar } \\
\text { İçinde }\end{array}$ & 247,587 & 247 & 1,002 & & \\
\hline & Toplam & 264,644 & 249 & & & \\
\hline \multirow[t]{3}{*}{$\begin{array}{l}\text { İhbar etmeyi düşünüyorsam hukuki } \\
\text { yollara başvururum }\end{array}$} & $\begin{array}{c}\text { Gruplar } \\
\text { arasinda }\end{array}$ & ,788 & 2 & ,394 & 2,251 & , 107 \\
\hline & $\begin{array}{l}\text { Gruplar } \\
\text { İçinde }\end{array}$ & 43,216 & 247 & , 175 & & \\
\hline & Toplam & 44,004 & 249 & & & \\
\hline \multirow[t]{3}{*}{\begin{tabular}{|l} 
İhbar etmeyi düşünüyorsam sosyal \\
ağlarda paylaşırım
\end{tabular}} & $\begin{array}{l}\text { Gruplar } \\
\text { arasinda }\end{array}$ & ,728 & 2 & ,364 & 1,574 & ,209 \\
\hline & $\begin{array}{l}\text { Gruplar } \\
\text { İçinde }\end{array}$ & 57,148 & 247 & ,231 & & \\
\hline & Toplam & 57,876 & 249 & & & \\
\hline \multirow[t]{3}{*}{$\begin{array}{l}\text { İhbar etmeyi düşünüyorsam kurum içinde } \\
\text { yönetime ihbarda bulunurum }\end{array}$} & $\begin{array}{l}\text { Gruplar } \\
\text { arasinda }\end{array}$ & 1,234 & 2 & ,617 & 2,974 & ,053* \\
\hline & $\begin{array}{l}\text { Gruplar } \\
\text { İçinde }\end{array}$ & 51,266 & 247 & ,208 & & \\
\hline & Toplam & 52,500 & 249 & & & \\
\hline \multirow[t]{3}{*}{$\begin{array}{l}\text { İhbar etmeyi düşünüyorsam kurum içinde } \\
\text { mesai arkadaşlarımla paylaşırım }\end{array}$} & $\begin{array}{l}\text { Gruplar } \\
\text { arasinda }\end{array}$ & ,094 & 2 & ,047 & ,190 & ,827 \\
\hline & $\begin{array}{l}\text { Gruplar } \\
\text { İçinde }\end{array}$ & 60,962 & 247 & ,247 & & \\
\hline & Toplam & 61,056 & 249 & & & \\
\hline \multirow[t]{3}{*}{$\begin{array}{l}\text { İhbar etmeyi düşünüyorsam kurum içinde } \\
\text { resmi prosedürleri kullanırım }\end{array}$} & $\begin{array}{l}\text { Gruplar } \\
\text { arasinda }\end{array}$ & 1,284 & 2 & ,642 & 2,610 & ,056* \\
\hline & $\begin{array}{l}\text { Gruplar } \\
\text { Içinde }\end{array}$ & 60,732 & 247 & ,246 & & \\
\hline & Toplam & 62,016 & 249 & & & \\
\hline \multirow{3}{*}{$\begin{array}{l}\text { İhbar etmeyi düşünmüyorsam kendime } \\
\text { zararı olacağını düşündügüm için } \\
\text { çekinirim ve ihbar etmem }\end{array}$} & $\begin{array}{l}\text { Gruplar } \\
\text { arasinda }\end{array}$ & 1,752 & 2 & ,876 & 3,659 & ,027* \\
\hline & $\begin{array}{l}\text { Gruplar } \\
\text { İçinde }\end{array}$ & 59,148 & 247 & ,239 & & \\
\hline & Toplam & 60,900 & 249 & & & \\
\hline \multirow[t]{4}{*}{$\begin{array}{l}\text { İhbar etmeyi düşünmüyorsam işten } \\
\text { atılmaktan korktuğum için ihbar etmem }\end{array}$} & $\begin{array}{l}\text { Gruplar } \\
\text { arasinda }\end{array}$ & ,406 & 2 & ,203 & ,864 & ,423 \\
\hline & $\begin{array}{l}\text { Gruplar } \\
\text { İçinde }\end{array}$ & 57,998 & 247 & ,235 & & \\
\hline & Toplam & 58,404 & 249 & & & \\
\hline & $\begin{array}{l}\text { Gruplar } \\
\text { arasinda }\end{array}$ & 2,210 & 2 & 1,105 & 5,343 & ,005* \\
\hline
\end{tabular}




\begin{tabular}{|c|c|c|c|c|c|c|}
\hline $\begin{array}{l}\text { İhbar etmeyi } \text { düşünmüyorsam } \\
\text { ayılplanmaktan ve } \\
\text { görülmekten korktuğum için ihbar etmem }\end{array}$ & $\begin{array}{l}\text { Gruplar } \\
\text { İçinde }\end{array}$ & 51,074 & 247 & ,207 & & \\
\hline \multirow{3}{*}{$\begin{array}{l}\text { İhbar etmeyi düşünmüyorsam ihbar } \\
\text { ettiğim kişi ya da kişilerin yaptırım } \\
\text { gücünden ve misillemeden korktuğum } \\
\text { için ihbar etmem }\end{array}$} & $\begin{array}{l}\text { Gruplar } \\
\text { arasında }\end{array}$ &, 174 & 2 & ,087 & ,372 & ,689 \\
\hline & $\begin{array}{l}\text { Gruplar } \\
\text { İçinde }\end{array}$ & 57,702 & 247 & ,234 & & \\
\hline & Toplam & 57,876 & 249 & & & \\
\hline \multirow{3}{*}{$\begin{array}{l}\text { İhbar etmeyi düşünmüyorsam } \\
\text { başkalarının tepki vermesini beklemeyi } \\
\text { tercih ettiğim için ihbar etmem }\end{array}$} & $\begin{array}{l}\text { Gruplar } \\
\text { arasinda }\end{array}$ & 2,518 & 2 & 1,259 & 12,623 &, $000 *$ \\
\hline & $\begin{array}{l}\text { Gruplar } \\
\text { İçinde }\end{array}$ & 24,638 & 247 &, 100 & & \\
\hline & Toplam & 27,156 & 249 & & & \\
\hline \multirow{3}{*}{$\begin{array}{l}\text { İhbar etmeyi düşünmüyorsam ihbar } \\
\text { ettiğim takdirde bile herhangi bir şeyin } \\
\text { düzelmeyeceğini düşündüğüm için ihbar } \\
\text { etmem }\end{array}$} & $\begin{array}{l}\text { Gruplar } \\
\text { arasinda }\end{array}$ & 1,309 & 2 & ,654 & 2,642 & ,073 \\
\hline & $\begin{array}{l}\text { Gruplar } \\
\text { İçinde }\end{array}$ & 61,175 & 247 & ,248 & & \\
\hline & Toplam & 62,484 & 249 & & & \\
\hline \multirow[t]{3}{*}{$\begin{array}{l}\text { İhbar etmeyi düşünmüyorsam kişilik } \\
\text { yapım gereği sessiz kalırım (ihbar etmem) }\end{array}$} & $\begin{array}{l}\text { Gruplar } \\
\text { arasinda }\end{array}$ & 1,174 & 2 & ,587 & 7,359 &, $001^{*}$ \\
\hline & $\begin{array}{l}\text { Gruplar } \\
\text { İçinde }\end{array}$ & 19,710 & 247 & ,080 & & \\
\hline & Toplam & 20,884 & 249 & & & \\
\hline
\end{tabular}

* \%10 anlamlıık düzeyinde anlamlıdır.

Analiz sonuçları değerlendirildiğinde Bilgi İfşasına İlişkin Görüşleri içeren "İhbarcılık, ahlaki bir davranıştır", "İhbarcılık, profesyonel olmanın bir gereğidir", "Gelecekte kendimi bir muhasebe meslek mensubu olarak hayal ettiğimde; ahlaki değerler benim için çok önemlidir", "İhbar yapan kişi, sorumluluk sahibi bir vatandaştır", "İhbar yapmak; hileyi, sahtekârlığı, yanlış yönetmeyi ve yozlaşmayı engeller", "İhbarcılık, ahlaki davranışları teşvik eder"," İşletmelerde meydana gelen usulsüzlük, haksızlık, dolandırıcılık gibi ahlaki olmayan bir davranış; eğer başkalarına zarar veriyorsa, bu durumu gerekli mercilere ihbar ederim", "İhbarcı olmayı çevremi korumak için tercih ederim", "Sadece başkaları da ihbar ettiğinde ve sonuçları gördüğümde ihbar etmeyi tercih ederim", "İhbarcılık, kamu yararını (kamu etkinliğini) artırmaya yardımcı olur", "İhbarcılık, yolsuzlukları önlemeye yardımcı olur", "İhbar etmeyi düşünüyorsam kurum içinde yönetime ihbarda bulunurum", "İhbar etmeyi düşünüyorsam kurum içinde resmi prosedürleri kullanırım", "İhbar etmeyi düşünmüyorsam kendime zararı olacağını düşündüğüm için çekinirim ve ihbar etmem", "İhbar etmeyi düşünmüyorsam ayıplanmaktan ve ispiyoncu olarak görülmekten korktuğum için ihbar etmem", "İhbar etmeyi düşünmüyorsam başkalarının tepki vermesini beklemeyi tercih ettiğim için ihbar etmem" ve "İhbar etmeyi düşünmüyorsam kişilik yapım gereği sessiz kalırım (ihbar etmem)" ifadeleri ile eğitim düzeyi arasında anlamlı bir farklılık olduğu görülmektedir.

Katılımcıların Bilgi İfşasına İlişkin Görüşleri ile Ailelerin ortalama gelir dağılımı arasındaki değerlendirme için oluşturulan hipotez şu şekildedir;

$\mathrm{H} 0=$ Katılımcıların Bilgi İfşasına İlişkin Görüşleri içeren ifadeler ile Ailelerin ortalama gelir dağılımı arasında anlamlı bir farklılık yoktur.

H1= Katılımcıların Bilgi İfş̧asına İlişkin Görüşleri içeren ifadeler ile Ailelerin ortalama gelir dağılımı arasında anlamlı bir farklılık vardır.

Elde edilen sonuçlar Tablo 8'de belirtildiği gibidir. 
Tablo 8. Anova Testi Sonuçları

\begin{tabular}{|c|c|c|c|c|c|c|}
\hline & & $\begin{array}{l}\text { Kareler } \\
\text { Toplamı }\end{array}$ & sd & $\begin{array}{c}\text { Kareler } \\
\text { Ortalaması }\end{array}$ & $\mathbf{F}$ & Sig. \\
\hline \multirow[t]{3}{*}{ İhbar yapan kişi kahramandır } & Gruplar arasında & 5,643 & 2 & 2,821 & 2,209 &, 112 \\
\hline & Gruplar İçinde & 315,461 & 247 & 1,277 & & \\
\hline & Toplam & 321,104 & 249 & & & \\
\hline \multirow[t]{3}{*}{ İhbarcılık, ahlaki bir davranıştır } & Gruplar arasinda & 1,430 & 2 & ,715 & 675 &, 510 \\
\hline & Gruplar İçinde & 261,470 & 247 & 1,059 & & \\
\hline & Toplam & 262,900 & 249 & & & \\
\hline \multirow{3}{*}{$\begin{array}{l}\text { İhbarcılık, profesyonel olmanın bir } \\
\text { gereğidir }\end{array}$} & Gruplar arasında & 1,228 & 2 & ,614 & ,454 & ,635 \\
\hline & Gruplar İçinde & 333,848 & 247 & 1,352 & & \\
\hline & Toplam & 335,076 & 249 & & & \\
\hline \multirow{3}{*}{$\begin{array}{l}\text { Gelecekte kendimi bir muhasebe } \\
\text { meslek mensubu olarak hayal } \\
\text { ettiğimde; ahlaki değerler benim için } \\
\text { çok önemlidir }\end{array}$} & Gruplar arasinda & 10,541 & 2 & 5,271 & 4,626 &, $011 *$ \\
\hline & Gruplar İçinde & 281,395 & 247 & 1,139 & & \\
\hline & Toplam & 291,936 & 249 & & & \\
\hline \multirow{3}{*}{$\begin{array}{l}\text { Sadece zorunlu kaldığımda ihbarcı } \\
\text { olmayı tercih ederim }\end{array}$} & Gruplar arasında & 12,652 & 2 & 6,326 & 3,829 &, $023 *$ \\
\hline & Gruplar İçinde & 408,052 & 247 & 1,652 & & \\
\hline & Toplam & 420,704 & 249 & & & \\
\hline \multirow{3}{*}{$\begin{array}{l}\text { İhbar yapan kişi, sorumluluk sahibi } \\
\text { bir vatandaştır }\end{array}$} & Gruplar arasında & 12,245 & 2 & 6,123 & 5,688 &, $004^{*}$ \\
\hline & Gruplar İçinde & 265,855 & 247 & 1,076 & & \\
\hline & Toplam & 278,100 & 249 & & & \\
\hline \multirow{3}{*}{$\begin{array}{l}\text { İhbar yapmak; hileyi, sahtekarlığı, } \\
\text { yanlıș yönetmeyi ve yozlaşmayı } \\
\text { engeller }\end{array}$} & Gruplar arasinda & 4,192 & 2 & 2,096 & 1,844 &, 160 \\
\hline & Gruplar İçinde & 280,724 & 247 & 1,137 & & \\
\hline & Toplam & 284,916 & 249 & & & \\
\hline \multirow{3}{*}{$\begin{array}{l}\text { İhbarcılık, ahlaki davranışları teşvik } \\
\text { eder }\end{array}$} & Gruplar arasında & 1,539 & 2 &, 769 &, 821 & ,441 \\
\hline & Gruplar İçinde & 231,361 & 247 & ,937 & & \\
\hline & Toplam & 232,900 & 249 & & & \\
\hline \multirow{3}{*}{$\begin{array}{l}\text { İşletmelerde meydana gelen } \\
\text { usulsüzlük, haksızlık, dolandırıcılık } \\
\text { gibi ahlaki olmayan bir davranış; eğer } \\
\text { başkalarına zarar veriyorsa, bu } \\
\text { durumu gerekli mercilere ihbar } \\
\text { ederim }\end{array}$} & Gruplar arasında & 7,018 & 2 & 3,509 & 3,949 &, $021 *$ \\
\hline & Gruplar İçinde & 219,482 & 247 & ,889 & & \\
\hline & Toplam & 226,500 & 249 & & & \\
\hline \multirow{3}{*}{$\begin{array}{l}\text { Sadece işletmeye etkisi çok büyükse, } \\
\text { suç içeren bir davranışı ihbar etmeyi } \\
\text { tercih ederim }\end{array}$} & Gruplar arasinda & 1,237 & 2 & 619 & ,417 & ,659 \\
\hline & Gruplar İçinde & 366,363 & 247 & 1,483 & & \\
\hline & Toplam & 367,600 & 249 & & & \\
\hline \multirow{4}{*}{$\begin{array}{l}\text { İhbarcı olmayı çevremi korumak için } \\
\text { tercih ederim }\end{array}$} & Gruplar arasında & 8,968 & 2 & 4,484 & 3,839 &, $023^{*}$ \\
\hline & Gruplar İçinde & 288,536 & 247 & 1,168 & & \\
\hline & Toplam & 297,504 & 249 & & & \\
\hline & Gruplar arasında & 2,494 & 2 & 1,247 & ,904 & ,406 \\
\hline
\end{tabular}




\begin{tabular}{|c|c|c|c|c|c|c|}
\hline \multirow{2}{*}{$\begin{array}{l}\text { İhbar etmeyi, ancak kendimi güvende } \\
\text { hissedersem tercih ederim }\end{array}$} & Gruplar İçinde & 340,770 & 247 & 1,380 & & \\
\hline & Toplam & 343,264 & 249 & & & \\
\hline \multirow{3}{*}{$\begin{array}{l}\text { Sadece başkaları da ihbar ettiğinde ve } \\
\text { sonuçları gördüğümde ihbar etmeyi } \\
\text { tercih ederim }\end{array}$} & Gruplar arasında & 2,183 & 2 & 1,092 & ,815 & ,444 \\
\hline & Gruplar İçinde & 330,761 & 247 & 1,339 & & \\
\hline & Toplam & 332,944 & 249 & & & \\
\hline \multirow{3}{*}{$\begin{array}{l}\text { İhbarcılık, kamu yararını (kamu } \\
\text { etkinliğini) artırmaya yardımcı olur }\end{array}$} & Gruplar arasında & 4,138 & 2 & 2,069 & 2,463 &, $087^{*}$ \\
\hline & Gruplar İçinde & 207,462 & 247 & ,840 & & \\
\hline & Toplam & 211,600 & 249 & & & \\
\hline \multirow{3}{*}{$\begin{array}{l}\text { İhbarcılık, yolsuzlukları önlemeye } \\
\text { yardımcı olur. }\end{array}$} & Gruplar arasında & 3,660 & 2 & 1,830 & 1,732 &, 179 \\
\hline & Gruplar İçinde & 260,984 & 247 & 1,057 & & \\
\hline & Toplam & 264,644 & 249 & & & \\
\hline \multirow{3}{*}{$\begin{array}{l}\text { İhbar etmeyi düşünüyorsam hukuki } \\
\text { yollara başvururum }\end{array}$} & Gruplar arasında &, 754 & 2 & ,377 & 2,154 &, 118 \\
\hline & Gruplar İçinde & 43,250 & 247 & ,175 & & \\
\hline & Toplam & 44,004 & 249 & & & \\
\hline \multirow{3}{*}{$\begin{array}{l}\text { İhbar etmeyi düşünüyorsam sosyal } \\
\text { ağlarda paylaşırım }\end{array}$} & Gruplar arasında & ,697 & 2 &, 348 & 1,505 &, 224 \\
\hline & Gruplar İçinde & 57,179 & 247 &, 231 & & \\
\hline & Toplam & 57,876 & 249 & & & \\
\hline \multirow{3}{*}{$\begin{array}{l}\text { İhbar etmeyi düşünüyorsam kurum } \\
\text { içinde yönetime ihbarda bulunurum }\end{array}$} & Gruplar arasinda &, 529 & 2 & ,265 & 1,258 & ,286 \\
\hline & Gruplar İçinde & 51,971 & 247 &, 210 & & \\
\hline & Toplam & 52,500 & 249 & & & \\
\hline \multirow{3}{*}{$\begin{array}{l}\text { İhbar etmeyi düşünüyorsam kurum } \\
\text { içinde mesai arkadaşlarımla } \\
\text { paylaşırım }\end{array}$} & Gruplar arasında & 033 & 2 & ,016 & ,066 & ,936 \\
\hline & Gruplar İçinde & 61,023 & 247 &, 247 & & \\
\hline & Toplam & 61,056 & 249 & & & \\
\hline \multirow{3}{*}{$\begin{array}{l}\text { İhbar etmeyi düşünüyorsam kurum } \\
\text { içinde resmi prosedürleri kullanırım }\end{array}$} & Gruplar arasında & ,167 & 2 & ,084 & ,334 &, 716 \\
\hline & Gruplar İçinde & 61,849 & 247 &, 250 & & \\
\hline & Toplam & 62,016 & 249 & & & \\
\hline \multirow{3}{*}{$\begin{array}{l}\text { İhbar } \quad \text { etmeyi } \\
\text { kendime } \\
\text { düşündünününüum } \\
\text { etmem }\end{array}$} & Gruplar arasında &, 159 & 2 &, 080 & ,324 &, 723 \\
\hline & Gruplar İçinde & 60,741 & 247 & ,246 & & \\
\hline & Toplam & 60,900 & 249 & & & \\
\hline \multirow{3}{*}{$\begin{array}{l}\text { İhbar etmeyi düşünmüyorsam işten } \\
\text { atılmaktan korktuğum için ihbar } \\
\text { etmem }\end{array}$} & Gruplar arasında &, 006 & 2 & ,003 & ,012 & ,988 \\
\hline & Gruplar İçinde & 58,398 & 247 & ,236 & & \\
\hline & Toplam & 58,404 & 249 & & & \\
\hline \multirow{3}{*}{$\begin{array}{l}\text { İhbar etmeyi düşünmüyorsam } \\
\text { ayılplanmaktan ve ispiyoncu olarak } \\
\text { görülmekten korktuğum için ihbar } \\
\text { etmem }\end{array}$} & Gruplar arasında & ,379 & 2 & ,189 &, 884 & ,414 \\
\hline & Gruplar İçinde & 52,905 & 247 &, 214 & & \\
\hline & Toplam & 53,284 & 249 & & & \\
\hline \multirow{2}{*}{$\begin{array}{l}\text { İhbar etmeyi düşünmüyorsam ihbar } \\
\text { ettiğim kişi ya da kişilerin yaptırım }\end{array}$} & Gruplar arasında &, 074 & 2 & 037 &, 158 &, 854 \\
\hline & Gruplar İçinde & 57,802 & 247 & ,234 & & \\
\hline
\end{tabular}




\begin{tabular}{|c|c|c|c|c|c|c|}
\hline $\begin{array}{l}\text { gücünden ve misillemeden } \\
\text { korktuğum için ihbar etmem }\end{array}$ & Toplam & 57,876 & 249 & & & \\
\hline \multirow{3}{*}{$\begin{array}{l}\text { İhbar etmeyi düşünmüyorsam } \\
\text { başkalarının tepki } \\
\text { beklemeyi tercih ettiğim } \\
\text { etmerin ihbar }\end{array}$} & Gruplar arasında &, 032 & 2 & ,016 &, 144 & ,866 \\
\hline & Gruplar İçinde & 27,124 & 247 & ,110 & & \\
\hline & Toplam & 27,156 & 249 & & & \\
\hline \multirow{3}{*}{$\begin{array}{l}\text { İhbar etmeyi düşünmüyorsam ihbar } \\
\text { ettiğim takdirde bile herhangi bir } \\
\text { şeyin düzelmeyeceğini düşündüğüm } \\
\text { için ihbar etmem }\end{array}$} & Gruplar arasında & ,136 & 2 & ,068 & ,269 & ,765 \\
\hline & Gruplar İçinde & 62,348 & 247 & ,252 & & \\
\hline & Toplam & 62,484 & 249 & & & \\
\hline \multirow{3}{*}{$\begin{array}{l}\text { İhbar etmeyi düşünmüyorsam kişilik } \\
\text { yapım gereği sessiz kalırım (ihbar } \\
\text { etmem) }\end{array}$} & Gruplar arasında & ,008 & 2 & ,004 & ,046 & ,955 \\
\hline & Gruplar İçinde & 20,876 & 247 & 085 & & \\
\hline & Toplam & 20,884 & 249 & & & \\
\hline
\end{tabular}

* \%10 anlamlılık düzeyinde anlamlıdır.

Analiz sonuçları değerlendirildiğinde Bilgi İ́şasına İlişkin Görüşleri içeren "Gelecekte kendimi bir muhasebe meslek mensubu olarak hayal ettiğimde; ahlaki değerler benim için çok önemlidir", "Sadece zorunlu kaldığımda ihbarcı olmayı tercih ederim", "İhbar yapan kişi, sorumluluk sahibi bir vatandaştır", "İ̧̧letmelerde meydana gelen usulsüzlük, haksızlık, dolandırıcılık gibi ahlaki olmayan bir davranış; eğer başkalarına zarar veriyorsa, bu durumu gerekli mercilere ihbar ederim", "İhbarcı olmayı çevremi korumak için tercih ederim", "İhbarcılık, kamu yararını (kamu etkinliğini) artırmaya yardımcı olur" ifadeleri ile aile içi ortalama gelir arasında anlamlı bir farklılık olduğu görülmektedir.

\section{SONUÇ}

Muhasebe meslek mensuplarının topluma karşı olan sorumlulukları, diğer meslek mensuplarına oranla daha fazladır. Bu çalışma bilgi ifş̧ası (whistleblowing) temel alınarak geleceğin muhasebe meslek mensupları olarak beklenen Ticaret Liseleri, İktisadi ve İdari Bilimler Fakültesi İşletme Bölümü lisans ve yüksek lisans öğrencilerinin bilgi ifşasına ilişkin görüşleri çerçevesinde şekillenmiştir.

Bilgi ifşası, ifşa edilecek olaydan etkilenebilecek kişi, kurum ve toplumu ilgili konu hakkında uyarmak amacıyla yapılmaktadır. Ek olarak bilgi ifşası hile davranışı gibi yüksek maliyetlere yol açan durumların tespit edilmesinde de kilit rol oynamaktadır. ACFE (2018) tarafından yayınlanan raporda herhangi bir raporlama biçimi kullanılmadığında bilgi ifşasını yapan kişilerin \%32'si doğrudan denetçiye, \%15'i yöneticiye, \%13'ü hile araştırma ekibine, \%12'si iş arkadaşına, \%10'u ise iç denetçiye yaptıkları belirtilerek günümüzde muhasebe skandallarını ve hile eylemlerinin engellenmesi ve/veya ortaya çıkartılmasında bilgi ifşasının önemine vurgu yapılmıştır.

Bilgi ifşasının etkin bir şekilde gerçekleştirebilmesi için uygun bir organizasyon ortamını hazırlanması gerekmektedir. İşletmenin gerek çalışanları gerekse ilişkili diğer kişi ve kurumları cesaretlendirecek bir misyona sahip olması bilgi ifşasının amacına uygun olarak gerçekleşmesine önemli katkı sağlayacaktır. Etkin bir bilgi ifşası ortamının oluşturulmasıyla işletme hem çalışanlar arasındaki dürüst iletişimi güçlendirmiş olacak hem de fonksiyonel denetim ve kontrol faaliyetlerinin etkinliğine katkı sağlayacaktır.

Çalışmada bilgi ifşasını içeren ifadelerin çeşitli demografik göstergelerden etkilenip etkilenmeyeceğini araştırılması amaçlanmıştır. Bu amaca dönük sonuçlar değerlendirildiğinde, ihbar yapmanın hileyi, sahtekârlığı, yanlış yönetmeyi ve yozlaşmayı engelleyeceği, işletmelerde meydana gelen usulsüzlük, haksızlık, dolandırıcılık gibi ahlaki olmayan bir davranış eğer başkalarına zarar veriyorsa bu durumun gerekli mercilere ihbar edilmesi ve ihbarcılı̆̆ın yolsuzlukları önlemeye yardımcı olacağı görüşü temel demografik faktörler açısından farklılık gösteren ortak bilgi ifşasını 
içeren ifadeler olarak ortaya çıkmıştır. Genel olarak değerlendirildiğinde katılımcılar ihbarcılığın gerek işletme gerek çevre gerekse kamu yararını korumak için olması gereken bir davranış biçimi olduğunu belirtmektedirler. Diğer yandan ihbar etmekten çekinen katılımcilarda genel olarak kendilerine zarar vereceği, ayıplanmaktan çekindiği ve başkalarının önce tepki vermesini beklediği görüşü yaygındır.

\section{KAYNAKÇA}

ACFE. (2018). "Report To The Nations: Global Study on Occupational Fraud and Abuse", 1-80.

Akın, O., Özdaşlı, K. (2014). "Muhasebe Meslek Mensuplarının Mesleki Faaliyetlerinde Uymaları Gereken Etik İlkelere Uyma Düzeyine Yönelik Meslek Mensupları İle Meslek Yüksek Okulu Muhasebe Bölümü Öğrencilerinin Algıları", Muhasebe ve Finansman Dergisi, Temmuz, 2014.

Aktan, C.C. (2006). "Organizasyonlarda Yanlış Uygulamalara Karşı Bir Sivil Erdem, Ahlaki Tepki ve Vicdani Red Davranışı: Whistleblowing", Mercek Dergisi, Ekim, 2006.

Alkan, G.İ. (2015). "Muhasebe Eğitiminde Etik: Ön Lisans Öğrencilerinin Etik Algılarına Yönelik Bir Araştırma", İşletme ve Ekonomi Araştırmaları Dergisi, Cilt 6 Sayı 2.

Alleyne, P., Weekes-Marshall, D., Arthur, R. 2012. "Exploring Factors Influencing Whistle-blowing Intentions among Accountants in Barbados", Journal of Eastern Caribbean Studies, Vol.38, 1-2.

Bayraktaroğlu, S., Özen Kutanis, R., Özdemir, Y. (2005). "Etik Eğitiminde Neredeyiz?: İktisadi ve İdari Bilimler Fakülteleri Örneği, İkinci Siyasette ve Yönetimde Etik Sempozyumu, 18-19 Kasım.

Bozkurt, N. (2016). "İşletmelerin Kara Deliği Hile”, Alfa Basım Yayın Dağıtım, Ekim 2016, İstanbul

Candan, H., Kaya, T. (2015). "İhbarcllık ve Algılanan Örgütsel Destek Arasındaki İlişskinin İncelenmesine Yönelik Bir Kamu Kurumunda Araştırma”, Kahramanmaraş Sütçü İmam Üniversitesi İktisadi ve İdari Bilimler Fakültesi Dergisi, Cilt 5, Sayı 2.

Celep, C., Konaklı, T. (2012). "Bilgi Uçurma: Eğitim Örgütlerinde Etik ve Kural Dışı Uygulamalara Yönelik Bir Tepki”, Uluslararası Eğitim Araştırmaları Dergisi, Cilt 3, Sayı 4.

Daştan, A., Bellikli, U., Bayraktar, Y. (2015). "Muhasebe Eğitiminde Etik İkilem ve Etik Karar Alma Konularına Yönelik KTÜ-İ̈BF Öğrencileri Üzerine Bir Araştırma", Bolu Abant İzzet Baysal Üniversitesi İ̉BF Ekonomik ve Sosyal Araştırmalar Dergisi, Bahar 2015.

Eweie, G., Brunton, M. (2009) "Ethical Perceptions of Business Students in a New Zealand University: Do Gender, Age and Work Experience Matter?", Journal of Business Ethics, 19, 1(2009).

Gülmez, C., Kıllı, M., Öz, B. (2016). "Üniversite Öğrencilerinin Muhasebe Meslek Etiğine Bakış Açılarının İncelenmesi OKÜ Öğrencileri Örneği”, Journal of Accouiting, Finance and Auditing Studies, Vol 2, Issue 3.

Hooks, K.L., Kaplan, S.E. and Schultz Jnr, J.J. (1994). 'Enhancing Communication to Assist in Fraud Prevention and Detection'. Auditing: A Journal of Practice and Theory, 13.

Kalaycı, Ş. (2010). SPSS Uygulamalı Çok Değişkenli İstatistik Teknikleri. Asil Yayıncılık.

King III, G. (1997). "The Implications of an Organization's Structure on Whistleblowing", Journal of Business Ethics, Vol 20, Issue 4.

Kozak, M.A., Şahin, S. (2018). "Bilgi İfşası (Whistleblowing) ve Etik İkilem Üzerine Çıkarımlar", Anatolia: Turizm Araştırmaları Dergisi, Cilt 29, Sayı 1.

Kurnaz, N., Ercan, C., Kestane, A. (2018). "Muhasebe Bilgi Kalitesi Ekseninde İç Denetim Ve Bilgi İfşası (Whistleblowing) İlişkisi”, Kastamonu Üniversitesi İ̈BF Dergisi, 20/1.

Label, W.A. ve Miethe, T.D. (1999). "Whistleblowing And External Auditors". The Journal of Applied Business Research, Vol. 15., No.2.

Lau, T.C., Choe, K. L. ve Ramly, Z. (2009). "Ethical Orientation Of Future Business Leaders: An Exploratory Research" International Review of Business Research Papers. 5; 1. 
Mesmer-Magnus, J.R. ve Viswesvaran, C. (2005). "Whistle-blowing in Organisations: An Examination of Correlates of Whistle-blowing Intentions, Actions and Retaliation". Journal of Business Ethics, 62 (3): $277-$ 297.

Miceli, M. P. ve Near. J. P. (1992). "Blowing the Whistle: The Organisational and Legal Implications for Companies and their Employees". New York: Lexington Books.

Miceli, M. P., Rehg, M., Near, J. P., \& Ryan, K. C. (1999). "Can laws protect whistle-blowers? results of a naturally occurring field experiment”. Work and Occupations, 26(1), 129-151.

Miceli, M.P, Near, J.P ve Dworkin, T.M. (2009). “A Word to the Wise: How Managers and Policy-Makers can Encourage Employees to Report Wrongdoing”. Journal of Business Ethics 86.

Miller, D. L., and S. Thomas. (2005). "The impact of relative position and relational closeness on the reporting of unethical acts". Journal of Business Ethics, 61 (4).

Mustapha, M., Siaw, L.S. (2012). "Will Final Year Accountancy Students Whistle Blow? A Malaysian Case", International Journal of Trade, Economics and Finance, Vol.3, No:5.

Near, J.P, Miceli, M.P. (1995). "Effective Whistle- Blowing”, Academy of Management Review, Vol 20, No 3.

Near, J.P., Miceli, M.P. (1985). "Organizational Dissidence: The Case of Whistle-Blowing", Journal of Business Ethics, 4.

O'Leary, R. (2014). The ethics of dissent: Managing guerrilla government (2nd ed.). Thousand Oaks, CA: CQ Press.

Öztürk, M.S. (2019). Denetimde Whistle Blowing Kavramının Önemi. Nobel Bilimsel Eserler.

Park, H., Rehg, M. T., Lee, D. (2005). "The Influence of Confucian Ethics and Collectivism on Whistleblowing Intentions: A Study of South Korean Public Employees”, Journal of Business Ethics, 58. 387 403

Pope, K. R., Lee, C. (2013). "Could the Dodd Frank Wall Street Reform and Consumer Protection Act of 2010 be helpful in reforming corporate America? An investigation on financial bounties and whistle-blowing behaviors in the private sector", Journal of Business Ethics 112 (4): 597-607.

Xu, Y., Ziegenfuss, D. (2008). "Reward Systems, Moral Reasoning, and Internal Auditors' Reporting Wrongdoing", Journal of Business and Psychology 22 (4): 323-331. 


\section{EXTENDED SUMMARY}

\section{Purpose}

Accounting scandals experienced in the world and effective on a global scale caused serious negativities for internal and external stakeholders. These scandals caused criticism from the accounting-related stakeholders. Accounting professionals have more responsibilities to society than other professionals. An important reason why scandals could not be prevented was evaluated as the unethical behaviors of the accounting professionals. Enron, WorldCom, Parmalat, Tyco etc. Unethical activities experienced in businesses have strengthened these criticisms (Alleyne et al., 2013: 36). After the accounting scandals that took place in the said enterprises and shook the whole world, many studies were made by different circles. These studies have many focal points. One of them draws attention as the studies on the concept of "whistleblowing" (Aktan, 2006: 1). Whistleblowing can be defined as explaining, communicating and attracting the attention of the legal and unethical behaviors that have occurred or are continuing in the institutions of the people who have worked or are currently working in an organization. Whistleblowing is done in order to warn the person, institution and society that may be affected by the event to be disclosed. In addition, information disclosure plays a key role in detecting high cost situations such as fraudulent behavior. In the report published by ACFE (2018), when no reporting format is used, $32 \%$ of the individuals who disclose information directly to the auditor, $15 \%$ to the manager, $13 \%$ to the fraud research team, $12 \%$ to their colleague, $10 \%$ to internal The importance of disclosure of information in preventing and / or revealing accounting scandals and fraudulent acts is emphasized by stating what they did to the auditor.

In the study, what are the opinions of future accounting professionals about information disclosure by evaluating the statements containing the opinions of the participants on whistleblowing? question is the focus of the study. Accordingly, the research question is shaped on whether there is an effect of various demographic factors on the evaluations regarding whistleblowing.

In this study, it is aimed to evaluate the opinions of the students of the Faculty of Economics and Administrative Sciences Department of Business Administration, graduate students and Commercial High School Accounting Department students, who are candidates for accounting professions of the future, on whistleblowing.

\section{Methodology}

In the study, in order to evaluate their views on whistleblowing, a survey was conducted on 250 students, consisting of undergraduate students of the Faculty of Economics and Administrative Sciences, Department of Business Administration, graduate students and Commercial High School Accounting Department students in 2021. The Information Disclosure Appraisal Questionnaire applied in the study was created by scanning the literature. Since the assumptions of parametric tests were met in the analyzes, parametric tests were used and the SPSS package program was used.

\section{Findings}

When some of the analysis results are evaluated, it is seen that the opinions regarding the statement "Reporting prevents cheating, fraud, mismanagement and corruption" differ in terms of gender. Accordingly, the male participants of reporting; they are more of the opinion that it prevents cheating, fraud, mismanagement, and corruption. The statement "An immoral behavior such as irregularity, unfairness, fraud occurring in businesses; if it harms others, I will report this to the necessary authorities" is also the opinion believed by the male participants, but it is seen that there are significant differences in this statement in terms of gender. Similarly, the view that whistleblowing will help prevent corruption is the view that is more widely accepted by male respondents.

\section{Conclusion and Discussion}

When the results obtained are evaluated, the view that reporting will prevent fraud, fraud, mismanagement and corruption, if an immoral behavior such as irregularity, unfairness, fraud in businesses harms others, this situation should be reported to the necessary authorities and reporting 
will help prevent corruption basic demographic factors. It has emerged as expressions containing common information disclosure that differ in terms of When evaluated in general, it can be stated that the reporting of the participants is a form of behavior that should be in order to protect the business, the environment and the public interest. On the other hand, it is common for participants who refrain from reporting that it will hurt themselves, avoid being condemned, and expect others to react first.

Accounting professionals have more responsibilities to society than other professionals. This study has been shaped within the framework of the opinions of the accounting professionals of the future on the disclosure of information based on whistleblowing. Information disclosure is carried out in order to warn the person, institution and society that may be affected by the event to be disclosed. In addition, disclosure plays a key role in detecting high-cost situations such as fraudulent behavior. 